\title{
Nicole LaViolette
}

It is with profound sadness that the Board of Editors learned of the death, on 22 May 2015, of Nicole LaViolette, Assistant to the Editors since volume 48 . Nicole LaViolette had achieved, well before her untimely death, widespread recognition and respect as a rigorous international lawyer and a devoted and gifted professor of public and private international law. Après un début de carrière comme adjointe législative sur la colline parlementaire à Ottawa suivant son premier diplôme (BA, Carleton University), Nicole obtint son diplôme en droit (ainsi que la médaille d'or) de l'Université d'Ottawa avant de poursuivre ses études supérieures en droit international à l'University of Cambridge en Angleterre. En 1998, elle est revenue à l'Université d'Ottawa, cette fois pour y combler un poste de professeure dans le Programme de common law en français. De 2007 à 2010 , elle occupa avec grande distinction le poste de vice-doyenne du Programme de common law en français, et en 2014 elle fut promue au rang de professeure titulaire.

Une enseignante bien-aimée, Nicole enseignait — en français et en anglais - le droit international public, le droit international privé, le droit international humanitaire, les droits de la personne, le droit des réfugiés, le droit de la famille et le droit des fiducies. Widely recognized for her dedication to pedagogical excellence and innovation, both at the undergraduate and graduate levels, she was a frequent recipient of teaching awards and a much sought-after (and generous) graduate student supervisor.

Nicole was also a prolific, multifaceted, and award-winning scholar. Perhaps best known for her ground-breaking work on refugee law and, in particular, its treatment of sexual minorities, Nicole was a world expert on issues of sexual orientation and gender identity in the refugee determination process. Her advice, training, and insights on these and related issues were much in demand, including by the United Nations High Commissioner for Refugees, the Immigration and Refugee Board of Canada, the International Commission of Jurists, parliamentary committees, and many others. Nicole also published copiously in such diverse areas as international human rights law, anti-terrorism law, Inter-American law, human trafficking (particularly of women and children), international criminal 
law, sexual minority rights, family law (comparative and domestic), and - reflecting her own passion for cycling and other sports cycling law. Indeed, she co-authored books on family and cycling law in 2014, even as she coped with her advancing illness.

Dévouée à l'épanouissement de la communauté juridique francophone ainsi qu'aux droits des minorités sexuelles, elle fut nommée membre de la Société honorifique de la Section de common law de l'Université d'Ottawa en 2006; reçu en 2014 l'Ordre du Mérite de l'Association des juristes d'expression française de l'Ontario; et fut décernée le Prix de l'héroïne de la Conférence sur l'orientation et l'identité sexuelles de l'Association du Barreau canadien en 2015.

Among her many scholarly pursuits, Nicole was a regular contributor to the pages of this Yearbook. ${ }^{1}$ She also lavished her considerable energy, organizational skills and editorial leadership on the Yearbook, joining the ranks of its editorial team as Assistant to the Editors in 2009. Dans ce rôle, elle s'occupait, entre autres, de la rubrique sur la pratique canadienne en matière de droit international (y-inclus les chroniques du Département des Affaires étrangères, Commerce et Développement, des mesures prises par le Canada en matière de traités, et des déclarations parlementaires). Également sous sa tutelle, les recensions d'ouvrages paraissant dans l'Annuaire ont connu une croissance marquée, tant au niveau de leur quantité que de leur qualité.

On a personal note, Nicole LaViolette was of great support to me when I assumed the role of Editor-in-Chief of the Yearbook, and throughout the subsequent years, as we collaborated as members of the editorial team. I will dearly miss her wise counsel, boundless energy, and good humour. The great courage and dignity with which she faced her final illness, and her remarkable lifetime of accomplishment and service, will continue to humble and inspire me for many years to come. Her death is a great loss to the Yearbook, to the international legal community in Canada and abroad, and to those of us who were fortunate enough to be able to call her colleague and friend.

JOHN H. GURRIE Editor-in-Chief

\footnotetext{
${ }^{1}$ Nicole LaViolette, "Commanding Rape: Sexual Violence, Command Responsibility, and the Prosecution of Superiors by the International Criminal Tribunals for the Former Yugoslavia and Rwanda" (1998) 36 Can YB Int'l Law 93; Nicole LaViolette, "L'importance de l'opinion publique: L'homoparentalité et la décision de la Cour européenne des droits de l'Homme dans l'affaire Fretté c. France" (2002) 40 ACDI 345 .
} 